UDC 339.137.2

DOI: $10.18524 / 2303-9914.2020 .1(36) .205178$

L. V. Tranchenko ${ }^{1}$, DrSc (Economic), Prof.

V. V. Yavorska ${ }^{2}$, DrSc (Geography), Prof.

O. M. Tranchenko' 1 PhD (Economic), Docent

V. A. Sych ${ }^{2}$, PhD (Geography), Docent.

K. V. Kolomiyets ${ }^{2}$, PhD (Geography), Docent.

${ }^{1}$ Uman National University of Horticulture,

Department of Tourism and Hotel and Restaurant Business,

ul. Institute, 1, Uman, Cherkasy region, 20305, Ukraine

${ }^{2}$ Odessa I. I. Mechnikov National University,

Department of Economic and Social Geography and Tourism,

Dvorianskaya St., 2, Odessa, 65082, Ukraine

yavorskaya@onu.edu.ua

\title{
THEORETICAL APPROACHES TO THE CREATION AND REALIZATION OF COMPETITIVE ADVANTAGES BY A TOURIST ENTERPRISE
}

The most important feature of a market economy is competition. Travel services as managed processes are influenced by the environment, the main part of which is competition. This means that tourism management takes into account the impact of competition when making management decisions. Travel firms do their work not in isolation, but based on the activities of other firms. In addition, the firm is focused on consumer interests. The purpose of the article is to consider the features of managing a travel company in a competitive environment and to substantiate methodological approaches to create and realize competitive advantages, which gives the tourism management a purposeful character. It is advisable to use SWOT analysis to identify the role of competition in the tourism industry. In terms of its role in tourism, SWOT analysis can be seen as an element of tourism management. When performing tourist services, it is envisaged to structure tourism factors according to the components of SWOT analysis. To this end, an examination of all the tools of tourism management and its manifestation in this tourism company and in the external environment. The SWOT analysis should be guided by the indicators of the ideal model of this tourism firm (benchmarking), which should be developed in the framework of tourism management. An integral part of competitive environment research is competition diagnostics. To diagnose competition in the tourist services market consists of the following stages: identification of travel companies located in this target market; collection of initial information; bringing natural, value and financial indicators to comparative attention; determining the type of market according to the marketing typology (seller's market, buyer's market); calculation of indicators that reflect the state of the market (by marketing methods); determination of the location of the tourist firm (market shares) at the end of the base and analyzed periods; calculation of indicators and in- 
dicators of competition;.calculation of the degree of market monopolization; factorial analysis of the dynamics of market shares of travel firms - competitors; choosing the type of statistical distribution of market shares; building a competitive map of the tourist market; situational analysis and forecasting of competition strategy in the market of a given travel company. These stages are specified using specially developed techniques - their variety allows you to choose the ones that best take into account the features of the functioning of the tourist services market. In order to evaluate the competitive environment of the tourist market, it is advisable to determine the indicators - competition indices.

Keywords: tourism, travel firm, management, competition, competitive environment.

\section{INTRODUCTION}

The most important feature of a market economy is competition. This feature is due to the fact that the interests of the subjects of the integrated market, especially similar or related activities, collide with each other, objectively generating hidden conflicts. Current norms and rules of business structures determine the boundaries and ethics of behavior in a competitive environment $[1,3,4,6]$.

In general, competition is a kind of obstacle to the promotion of goods and services for their sale in order to obtain revenue that can cover all costs in excess of profits. This obstacle is overcome by the competitiveness of the firm. Tourism services as managed processes are influenced by the external environment, the main part of which is competition. This means that in making management decisions, tourism management takes into account the impact of competition. In principle, the management decision depends on a number of factors (cost of the tour, season, set of services, modes of transport, categories of hotel services, etc.). However, the impact of competition, in our estimation, is $50-70 \%$.

The prevalence of competition is the reason for the presence in scientific and practical circulation of many of its definitions. The following definition seems to be the most adequate for the tourism industry: it is "the economic process of interaction, interconnection and struggle, communications of the subjects of the market system in the process of creation, sale and consumption of material and spiritual goods" [5].

This definition reflects all aspects of the functioning of the tourism market, with special emphasis on the provision that competition is not only a struggle, but also an interaction and relationship. In other words, travel companies do their work not in isolation from each other, but taking into account the activities of other companies. In addition, the company focuses on the interests of consumers, not only material but also spiritual benefits, which is very important for tourism. Competition as a phenomenon of market economy serves as an incentive for the development and implementation of innovations in order to achieve competitive advantage [7, 9, 11]. Hence the need for each subject of the tourist market in its daily activities to seek and maintain their competitive advantages. It follows that competition serves the interests of consumers and is therefore beneficial. 
In this regard, it is appropriate to give the following definition: competition is "a regulator of market relations, a stimulator of scientific and technological progress and efficiency of social production" [8]. The latter judgment is very important, because the role of the tourism industry in GDP is quite large and constantly growing. When setting the problem, it is necessary to consider the features of the competitive environment in the market of tourist services and its impact on the competitiveness of economic entities in this market.

Many Ukrainian scientists and practitioners are attracted to the management of travel companies in a competitive environment, as today this area is promising. In particular, theoretical and methodological principles were developed in the works of V. V. Abramov [10], V. V. Alexandrov [11], M. O. Baranovsky [1], L. D. Bozhko [2], M. V. Grabar, V. A. Bigori [3], O. V. Hryvkivska [4], T. V. Hrynko [5], O. Davydova [6], A. Matvienko [7], S. G. Nezdoiminov [8], T. I. Tkachenko [9] and others. The well-known works of the above scientists are of great importance in terms of solving the problems of travel agency management in a competitive environment. First of all, they are a scientific and theoretical basis for further development of theoretical and methodological principles of management using SWOT-analysis, benchmarking and to develop methodological approaches to creating and implementing competitive advantages, which gives tourism management a purposeful nature. All this determines the need and relevance of the study of this article.

The purpose of the article is to consider the features of managing a travel agency in a competitive environment and substantiate the methodological approaches to the creation and implementation of competitive advantages, which gives tourism management a purposeful nature.

\section{DATA AND METHODS}

To identify the role of competition in the tourism industry, it is advisable to use SWOT-analysis $[2,10]$. In terms of its role in tourism, SWOT analysis can be seen as an element of tourism management. In the conventional form SWOT-method of qualitative analysis in strategic planning, which consists in the division of factors and phenomena into four categories: Strengths - strengths; Weaknesses - weaknesses; Opportunities - opportunities; Threats - threats.

These components of the analysis are correlated with the internal and external environment. Internal environment - the commercial activities of this travel agency, carried out on the principles and methods of tourism theory. The external environment means the market and institutional infrastructure with which the travel agency interacts. In this case, the external environment also includes business partners. Execution in practice of SWOT-analysis is carried out according to the presented matrix (tab. 1).

When performing tourist services, the structuring of tourism factors according to the components of SWOT-analysis is envisaged. To this end, the examination of all tools of tourism management and its manifestations in this travel agency and in 
the external environment. When conducting a SWOT-analysis should be guided by the indicators of the ideal model of the travel agency (benchmarking), which should be developed in the framework of tourism management. It should be borne in mind that benchmarking is based on the competitive advantages of other travel companies operating in this market segment $[1,3]$. For examination for the purpose of SWOT-analysis of the travel company the scheme is offered (tab. 2).

Table 1

General scheme of SWOT-analysis $[6,7]$

\begin{tabular}{|c|c|c|}
\hline Environment & Positive impact & Negative impact \\
\hline Internal environment & Strengths & Weaknesses \\
\hline External environment & Opportunities & Threats \\
\hline
\end{tabular}

Table 2

\section{General SWOT-analysis in tourism *}

\begin{tabular}{|c|l|l|}
\hline Environment & \multicolumn{1}{|c|}{ Positive impact } & \multicolumn{1}{|c|}{ Negative impact } \\
\hline \multirow{2}{*}{$\begin{array}{l}\text { Internal } \\
\text { of tourism theory. } \\
\text { Taking into account the individual } \\
\text { wishes of tourists. Diversification of } \\
\text { tourist services. } \\
\text { Innovative activity: development } \\
\text { and implementation of new forms of } \\
\text { tourist services. } \\
\text { Effective tourism management and } \\
\text { advertising: the competitiveness of } \\
\text { a travel agency }\end{array}$} & $\begin{array}{l}\text { Limitation: } \\
\text { qualification and professionalism of } \\
\text { staff; financial capabilities of this } \\
\text { travel agency; } \\
\text { availability of hotel places; environ- } \\
\text { mental requirements; requirements } \\
\text { of supervisory bodies and inspec- } \\
\text { tions; the availability and level of } \\
\text { technical means used to service } \\
\text { tourists }\end{array}$ \\
\hline $\begin{array}{l}\text { External } \\
\text { environment }\end{array}$ & $\begin{array}{l}\text { Competition and interaction with } \\
\text { partners in the processes of tourist } \\
\text { services }\end{array}$ & $\begin{array}{l}\text { Lack of interaction, violation of the } \\
\text { tourist service regime, inaccurate or } \\
\text { incomplete information about the } \\
\text { situation on the tourist market }\end{array}$ \\
\hline
\end{tabular}

* Developed by authors on the basis of: 5,7

\section{RESULTS AND DISCUSSION}

The positive impact of tourism management is manifested in the internal environment, as the main indicators are largely controlled and are within the competence of the travel agency. The purpose of management in any case is to ensure the competitiveness of the travel agency.

The negative impact in the domestic environment is primarily due to the level of qualification and professionalism of tourism staff, their ability to operate the tools of tourism theory in the implementation of processes and operations of tourist services. Within the internal environment, the financial condition of the company can have a negative impact, because the lack of financial resources can constrain the complete- 
ness and scope of application of tourism management tools. In general, the internal environment can be brought to the requirements of tourism management to achieve the competitiveness of the firm in the market of travel services.

The external environment is in most cases uncontrolled and therefore requires constant monitoring. The results of such monitoring provide the necessary initial data, especially on the state of the competitive environment, for the development of innovative measures. From the point of view of SWOT-analysis, competition cannot be attributed to the weaknesses of a travel agency - on the contrary, with its usefulness, competition should be considered a strength. So, the strength, of course, is the competitiveness of this travel agency.

Component diagnostics is an integral part of the study of the competitive environment. To diagnose competition in the market of tourist services consists of the following stages $[2,7,11]$ :

1. Identification of travel companies in this target market;

2. Collection of source information;

3. Bringing natural, cost and financial indicators to a comparable attention;

4. Determining the type of market according to the typology of marketing (seller's market, buyer's market);

5. Calculation of indicators that reflect the state of the market (according to marketing methods);

6. Determining the place of the travel company (market shares) at the end of the base and analyzed periods;

7. Calculation of indicators of competition;

8. Calculation of the degree of market monopolization;

9. Factorial analysis of the dynamics of market shares of travel companies - competitors;

10. Choice of the type of statistical distribution of market shares;

11. Construction of a competitive map of the tourist market;

12. Situational analysis and forecasting of competition strategy in the market of this travel company.

These stages are specified using specially designed techniques - their diversity allows you to choose those that best take into account the peculiarities of the market of tourist services. To assess the competitive environment of the tourism market it is advisable to determine indicators - competition indices [5].

Diagnosis of the competitive environment in tourism should become an integral part of tourism management. According to the theory and practice of management, the competitive environment should be differentiated by segments of the tourism market, in particular, the following segments can be proposed:

1. By directions (routes) of current tours;

2. By types of tourism - recreational, cognitive, excursion, extreme, etc .;

3. On a set of the offered tourist services - on a package of services;

4. On the basis of seasonality - the seasons; 
5. The composition of tourist groups - general, youth, professional, special, etc.;

6. By price structure (tours by classes: exclusive, premium, economy).

Thus, a clear and reliable knowledge of the competitive environment is a necessary condition for the formation of competitive advantages, which gives tourism management a purposeful nature.

Tourist services as items of sale have a commodity nature. Therefore, in order to objectively assess competition and competitiveness, the life cycle of travel services should be monitored. In principle, the life cycle of tourist services as a commodity is quite standard. In addition, the need for innovation is due to the fact that the tourist product as a commodity is characterized by its life cycle. The life cycle is also possessed by such components of tourist activity as technology, equipment, organizational forms of tourism, personnel qualification [6].

In the general case, the life cycle includes the following stages (Fig. 1).

1. Development of tourist services as a commodity.

2. Bringing a tourist product to market.

3. Growth of sales of this tourist product.

4. Maturity of the tourist product.

5. Decline in sales and extinction of the tourist product.

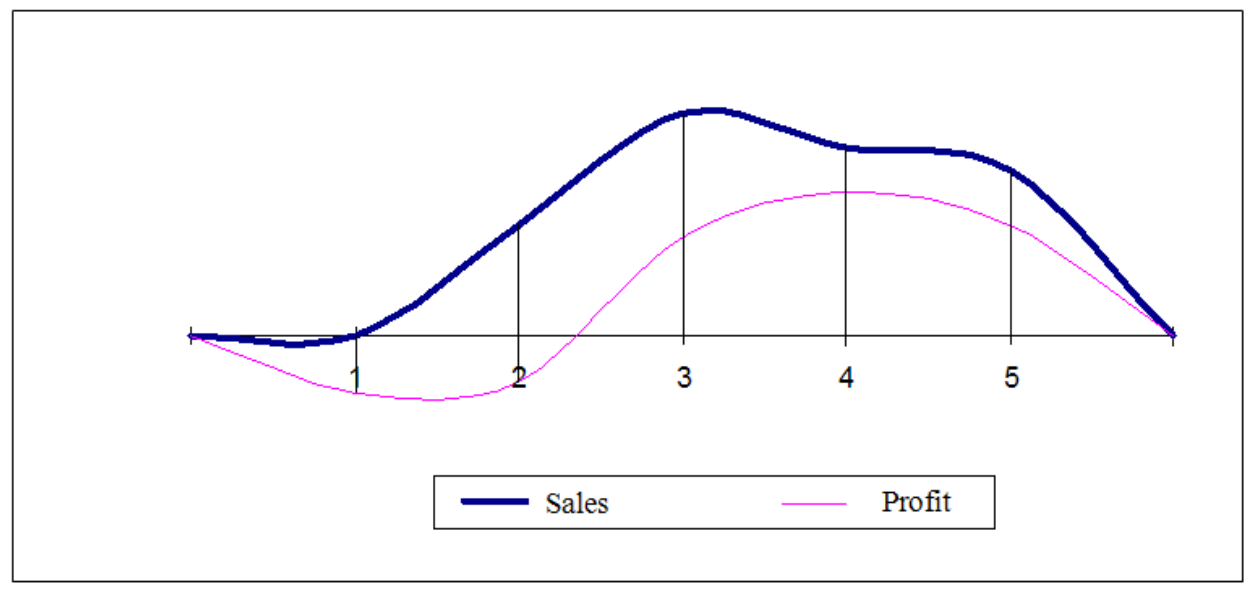

Fig. 1. Product life cycle (services) [7]

The need to monitor the life cycle is determined by the analysis of the tourist product and consumer behavior of the individual tourist. With the help of the life cycle, the strengths and weaknesses in the implementation of tourist vouchers are identified. Knowing at what stage of the life cycle is the tourism product, the company needs to develop specific measures of its competition policy and control its competitiveness.

The determining factor of competitiveness in the field of tourism is the attractiveness of the tourist product, in contrast to the competitiveness of the product in kind, 
where the determining factor is its functional and consumer properties.

To form the competitiveness of the tourist product should be guided by the following factors:

- the ratio of the value of the product price of the travel agency with the prices of competing firms;

- general characteristics of the competition policy of competing travel companies;

- the possibility of price differentiation depending on the situation in the tourism market - from supply and demand;

- system of discounts on the price of tourist services;

- the presence of assortment diversification of the tourist product from the standpoint of meeting competitive needs;

- brand presence and effectiveness of advertising information;

- development of quality guarantees for the provision of tourist services.

These factors should correspond to the above segments of the tourism market, accepted as objects of competitive diagnostics. Another important condition for competitiveness is the reputation of the travel company: it is the reputation that has an attractive force and inspires confidence from consumers of travel services.

In the modern economy there is a situation as a result of which the competitive environment in the consumer market is significantly distorted by the predominance of network trade, especially food products. This situation is characterized by a fairly high level of monopoly, which negatively affects the interests of consumers. In this regard, the competitive environment of the tourism market is in a more favorable position.

Travel companies operate almost autonomously, so competition in the tourism market in the first approximation can be considered perfect. In perfect competition its positive qualities for the consumer are fully revealed. However, for the market participant, according to economic theory, profitability tends to the minimum value. Therefore, in practice there is a significant deviation from perfect competition. In this regard, there are two types of competition: price and non-price.

With price competition, a travel company seeks success by lowering the price of its product. Thus, such competition is based on reducing the total costs (costs) of their activities. Naturally, the magnitude of the price reduction is focused on the level of prices for similar travel services of competing firms. In other words, the sale of a tourist product is carried out at lower prices than competitors. In some cases, this firm loses part of its profits.

Within the framework of this type of competition requires an active pricing policy of the travel agency, which provides for the differentiation of tour prices within a fairly wide range, as well as the availability of a system of price discounts. International commercial practice recommends giving discounts to each buyer at least as a sign of gratitude for the fact that the buyer turned to this company.

It should be noted that not every travel agency is able to take advantage of price competition. In this case, non-price competition is used. In general, non-price com- 
petition is based on the sale of higher quality goods, as well as the use of marketing methods, advertising campaigns, the development of new segments of the tourism market. In the tourism industry, the innovative activity of the company plays an important role in non-price competition: new tours, new service packages, new brands. Non-price competition involves holding special promotions, including in the form of targeted advertising campaigns.

An important component in the set of competitive advantages is the formation of a permanent clientele of this travel company. In this regard, the travel company should also focus on serving VIP-clients. Possessing innovative tools, the travel company becomes a kind of monopolist, which allows it to increase the volume of its activities, and with it the profit and strengthen its financial position. At the same time, such "innovation monopoly" does not fall under the scope of antitrust law and this should be used by travel agencies.

Entrepreneurial activity is based on continuous innovation activity, but for tourism innovations, as it was said, play a primary role. This means that in each tourist season, the company must offer real and potential tourists new conditions in terms of direction and content, taking into account the results of tourism activities in previous years.

Local history provides a great source of information material for domestic tourism and regional studies for international tourism. In general, the activities of a travel agency should be transparent in the openness and personalization of the company's specialists, indicating their qualifications and professional qualities.

\section{CONCLUSIONS}

Thus, the presented material shows how deep and multifaceted the problem of competition and competitiveness in the tourism industry is. At the same time, this problem has not been properly studied in order to develop practical recommendations. Therefore, the formation of a special theory of tourist competition is quite relevant. Competition and competitiveness in the field of tourism have a pronounced specificity, which must be taken into account in tourism management by adapting the basic provisions of competition theory.

\section{REFERENCES}

1. Baranovs'kyy, M. (2008), Turyzm yak forma aktyvizatsiyi rozvytku sil's'kykh depresyvnykh terytoriy [Tourism as a form of activation of rural depressed territories], Visnyk L'vivs'koho universytetu. Seriya Mizhnarodni vidnosyny, Vol. 24, pp. 13-21.

2. Bozhko, L. D. (2011), Internet yak zasib sotsial'nykh komunikatsiy u turyzmi [Elektronnyy resurs] / L. D. Bozhko // Visnyk Kharkivs'koyi derzhavnoyi akademiyi kul'tury, Vol. 32, pp. 245-254

3. Hrabar, M. V., Bihori V. A. (2013), Systemnyy pidkhid v upravlinni rozvytkom sferoyu turyzmu ta rekreatsiyi [A systematic approach in managing the development of tourism and recreation], Ekonomichnyy prostir, vol. 72, pp. 35-45.

4. Hryvkivs'ka, O. V. (2012), Otsinka isnuyuchykh pidkhodiv do biznes-planuvannya hospodars'koyi diyal'nosti turystychnykh pidpryyemstv [Assessment of existing approaches to business planning of business activities of tourism enterprises], Investytsiyi: praktyka ta dosvid, vol. 9, pp. 47-49. 
5. Hryn'ko, T. V. (2013), Udoskonalennya upravlinnya pidpryyemstvamy turystychnoyi sfery [Improving the management of tourism enterprises], Ekonomika. Finansy. Pravo, vol. 5, pp. 13-15.

6. Davydova, O. (2011), Osoblyvosti innovatsiynykh protsesiv u sferi turystychnykh posluh [Features of innovative processes in the field of tourist services], Problemy nauky, vol. 5, pp. 16-21.

7. Matviyenko, A. (2011), Derzhavna polityka u sferi turyzmu: dokumental'ne zabezpechennya [State Tourism Policy: Documentary Support], Naukovi pratsi Natsional'noyi biblioteky Ukrayiny im. V. I. Vernads'koho, Vol. 31, pp.312-323.

8. Nezdoyminov, S. H. (2009), Turyzm yak faktor rehional'noho rozvytku. Metodolohichnyy aspekt ta praktychnyy dosvid : monohrafiya [Tourism as a factor of regional development. Methodological Aspect and Practical Experience: A Monograph], Odessa: Astroprynt, 304 p.

9. Tkachenko, T. I. (2009), Stalyy rozvytok turyzmu: teoriya, metodolohiya, realiyi biznesu: monohrafiya [Sustainable development of tourism: theory, methodology, business realities: monograph], K.: KNTEU, 463 p.

10. Abramov, V. V., Andrenko, I. B., Aleksandrova, S. A. ta in. (2012), Turyzm i misto: analiz problem, tendentsiy ta modelyuvannya rozvytku : monohrafiya [Tourism and the city: analysis of problems, tendencies and modeling of development: monograph], Kharkiv: KhNAMH, 208 p.

11. Aleksandrov, V. V., Vy`shnevs `ka, O. O., Volkova, I. I. ta in. (2010), Tury ‘zm v sy ‘stemi priory `tetiv regional nogo rozvy 'tku: monografiya [Tourism in the system of priorities of regional development: monograph], Kharkiv: KhNU im. V.N. Karazina, 268 p.

\section{СПИСОК ВИКОРИСТАНОЇ ЛІТЕРАТУРИ:}

1. Барановський М. Туризм як форма активізації розвитку сільських депресивних територій [Текст] / М. Барановський // Вісник Львів. ун-ту. Сер. Міжнародні відносини, 2008. - Вип. 24. - C. 13-21.

2. Божко Л. Д. Інтернет як засіб соціальних комунікацій у туризмі [Текст] / Л. Д. Божко // Вісник Харківської державної академії культури, 2011. - Вип. 32. - С. 245-254.

3. Грабар М. В. Системний підхід в управлінні розвитком сферою туризму та рекреації [Текст] / М. В. Грабар, В. А. Бігорі // Економічний простір, 2013. - № 72. - С. 35-45.

4. Гривківська О. В. Оцінка існуючих підходів до бізнес-планування господарської діяльності туристичних підприємств / О.В. Гривківська [Текст] // Інвестиції: практика та досвід, 2012. - №9. - С. 47-49.

5. Гринько Т. В. Удосконалення управління підприємствами туристичної сфери [Текст] / Т.В.Гринько // Економіка. Фінанси. Право, 2013. - № 5. - С. 13-15.

6. Давидова О. Особливості інноваційних процесів у сфері туристичних послуг [Текст] / О. Давидова // Проблеми науки, 2011. - № 5. - С. 16-21.

7. Матвієнко А. Державна політика у сфері туризму: документальне забезпечення [Текст] / А. Матвієнко // Наукові праці Національної бібліотеки України ім. В. І. Вернадського, 2011. - Вип. 31. - С. 312-323.

8. Нездоймінов С. Г. Туризм як фактор регіонального розвитку. Методологічний аспект та практичний досвід : монографія [Текст] / С. Г. Нездоймінов. - Одеса: Астропринт, 2009. $304 \mathrm{c}$.

9. Ткаченко Т. І. Сталий розвиток туризму: теорія, методологія, реалії бізнесу: монографія [Текст] / Т.І. Ткаченко. - К.: КНТЕУ, 2009. - 463 с.

10. Туризм і місто: аналіз проблем, тенденцій та моделювання розвитку: монографія [Текст] / В. В. Абрамов, І. Б. Андренко, С. А. Александрова, Н. М. Влащенко, О. М. Колесников; ред. І. М. Писаревський. - Х.: ХНАМГ, 2012. - 208 с.

11. Туризм в системі пріоритетів регіонального розвитку: монографія [Текст] / В. В. Александров, О. О. Вишневська, І. І. Волкова та ін. - Х.: ХНУ ім. В.Н. Каразіна, 2010. - 268 с.

Надійшла 01.04.2020 
Л. В. Транченко ${ }^{1}$, доктор економ. наук, професор

В. В. Яворська ${ }^{2}$, доктор геогр. наук, професор

О. М. Транченко ${ }^{1}$, канд. економ. наук, доцент

В. А. Сич² ${ }^{2}$ канд. геогр. наук, доцент

К. В. Коломієць ${ }^{2}$, канд. геогр. наук, доцент

${ }^{1}$ Уманський національний університет садівництва,

кафедра туризму та готельно-ресторанної справи,

вул. Інститутська, 1, м. Умань, Черкаська обл., 20305, Україна

lydatranch@gmail.com

${ }^{2}$ Одеський національний університет імені I. І. Мечникова,

кафедра економічної та соціальної географії і туризму,

вул. Дворянська 2, м. Одеса, 65082, Україна

yavorskaya@onu.edu.ua

\section{ТЕОРЕТИЧНІ ПІДХОДИ ЩОДО СТВОРЕННЯ I РЕАЛІЗАЦЇ̈ КОНКУРЕНТНИХ ПЕРЕВАГ ТУРИСТИЧНИМ ПІДПРИЕМСТВОМ}

Резюме

У статті розглянуто теоретичні аспекти управління туристичною фірмою у конкурентному середовищі. Метою статті $є$ розгляд особливостей управління туристичною фірмою в конкурентному середовищі і обгрунтування методичних підходів щодо створення і реалізації конкурентних переваг, що додає туристичному менеджменту цілеспрямований характер. Розкрито особливості застосування SWOT-аналізу, бенчмаркінгу, який повинен розроблятися в рамках туристичного менеджменту. При виконанні туристичного обслуговування передбачається структурування факторів туризму за складовими SWOT-аналізу. 3 цією метою проводиться експертиза всього інструментарію туристичного менеджменту і його прояви в даній туристичній фірмі і в зовнішньому середовищі. Проаналізовано етапи діагностики конкуренції на ринку туристичних послуг. Запропоновано фактори для формування конкурентоспроможності туристичного продукту. Доведено, що чітке і достовірне знання стану конкурентного середовища $є$ необхідною умовою для формування конкурентних переваг, що додає туристичному менеджменту цілеспрямований характер.

Ключові слова: туризм, туристична фірма, управління, конкуренція, конкурентне середовище. 
Л. В. Транченко ${ }^{1}$, доктор эконом. наук, профессор

В. В. Яворская ${ }^{2}$, доктор геогр. наук, профессор

О. М. Транченко ${ }^{1}$, канд. эконом. наук, доцент

В. А. Сыч², канд. геогр. наук, доцент

Е. В. Коломиец ${ }^{2}$, канд. геогр. наук, доцент

${ }^{1}$ Уманьский национальный университет садоводства,

кафедра туризма и отельно-ресторанного дела,

ул. Институтская, 1, г. Умань, Черкасская обл., 20305, Украина

lydatranch@gmail.com

${ }^{2}$ Одесский национальный университет имени И. И. Мечникова,

кафедра экономической и социальной географии и туризма,

ул. Дворянская 2, г. Одесса, 65082, Украина

\section{ТЕОРЕТИЧЕСКИЕ ПОДХОДЫ К СОЗДАНИЮ И РЕАЛИЗАЦИИ КОНКУРЕНТНЫХ ПРЕИМУЩЕСТВ ТУРИСТИЧЕСКИМ ПРЕДПРИЯТИЕМ}

\section{Резюме}

В статье рассмотрены теоретические аспекты управления туристической фирмой в конкурентной среде. Раскрыты особенности применения SWOT-анализа, бенчмаркинга, который должен разрабатываться в рамках туристического менеджмента. Проанализированы этапы диагностики конкуренции на рынке туристических услуг. Предложены факторы для формирования конкурентоспособности туристического продукта. Доказано, что четкое и достоверное знание состояния конкурентной среды является необходимым условием для формирования конкурентных преимуществ, что добавляет туристическому менеджменту целенаправленный характер.

Ключевые слова: туризм, туристическая фирма, управление, конкуренция, конкурентная среда. 